\title{
Extracellular matrix surface network is associated with non- morphogenic calli of Helianthus tuberosus cv. Albik produced from various explants
}

\author{
Maria Pilarska', Marzena Popielarska-Konieczna ${ }^{1 *}$, Halina Ślesak' , Małgorzata Kozieradzka-Kiszkurno²,

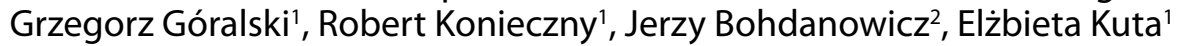 \\ ${ }^{1}$ Department of Plant Cytology and Embryology, Jagiellonian University, Gronostajowa 9, 30-387 Cracow, Poland \\ 2 Department of Plant Cytology and Embryology, University of Gdańsk, Wita Stwosza 59, 80-308 Gdańsk, Poland
}

\section{Abstract}

Helianthus tuberosus is economically important species. To improve characters of this energetic plant via genetic modification, production of callus tissue and plant regeneration are the first steps. A new, potentially energetic cultivar Albik was used in this study to test callus induction and regeneration. Callus was produced on leaves, petioles, apical meristems and stems from field-harvested plants but was totally non-morphogenic. Its induction started in the cortex and vascular bundles as confirmed by histological analysis. The surface of heterogeneous callus was partially covered with a membranous extracellular matrix surface network visible in scanning and transmission electron microscopies. The results clearly indicate that: $(\boldsymbol{i})$ the morphogenic capacity of callus in topinambur is genotype dependent, (ii) cv. Albik of $H$. tuberosus proved recalcitrant in in vitro regeneration, and (iii) extracellular matrix surface network is not a morphogenic marker in this cultivar.

Keywords: callogenesis; extracellular matrix; in vitro culture; scanning electron microscopy; topinambur; transmission electron microscopy

\section{Introduction}

Helianthus tuberosus (Jerusalem artichoke, topinambur, earth apple) is a perennial warm-season species of sunflower native to temperate regions of North America that has been known in Europe since the 17th century. It is an agricultural plant with nutritional, medicinal and energy potential. Its tubers are rich in polysaccharide inulin. The species is also cultivated for biofuels [1]. A new, cold resistance cultivar Albik was selected for further improvement (e.g., more intensive growth and cellulose production) through genetic transformation with the use of in vitro technique.

Topinambur was investigated in different aspects. Recently, phytochemical studies revealed the bioactive metabolites with medicinal value $[1,2]$. Microtubers induction in tissue culture was used for simulating physiological processes leading to underground storage organ formation [3]. Some efforts for the successful cryopreservation protocol were also undertaken [4]. So far the low efficiency of plant regeneration

\footnotetext{
*Corresponding author. Email: m.popielarska-konieczna@uj.edu.pl
} Handling Editor: Beata Zagórska-Marek via indirect organogenesis or somatic embryogenesis was described in the leaf culture of Helianthus tuberosus and in anther or root culture of tetraploid interspecific hybrid Helianthus annuus $\times$ Helianthus tuberosus [5-7].

An in vitro cell and tissue culture induces different cellular responses that mediate adaptations under new environmental conditions. Cells with a morphogenetic or embryogenic potential differ from a non-regenerative callus in several features, including cell wall modifications [8]. The formation of extracellular strands, fibrils and/or a continuous layer over callus cells accompanies the induction of morphogenesis in many plants cultured in vitro. This structure, which is referred to as extracellular matrix (ECM) or extracellular matrix surface network (ECMSN), has been found during the early stages of somatic embryogenesis and organogenesis e.g., in coconut [8] and maize [9]. The exact role of this structure is still not known, but its regulatory and coordinating functions during the early stages of morphogenesis have been suggested $[8,10-13]$.

The aim of this study was to establish protocols of callus induction and then the plant regeneration and to see whether ECMSN can be treated as a morphogenic marker of the investigated cultivar. This is the first attempt to test the morphogenetic ability of topinambur cv. Albik. 


\section{Material and methods}

\section{Culture conditions}

About 100 mature plants of $H$. tuberosus cv. Albik, vegetatively propagated from tubers obtained from IHAR (Radzików, Poland), harvested in Polanka Hallera and Modlnica (experimental fields of Jagiellonian University, near Cracow, Poland), were the sources of the following explants: apical meristems, petioles $(10 \mathrm{~mm})$ different leaf segments $(10 \times 15 \mathrm{~mm})$ and $2-3 \mathrm{~mm}$ thick stem fragments. Tuber and root segments were excluded from the study because of high contamination rate: $80-90 \%$ in preliminary tests. Plant material was surface sterilized for $70 \mathrm{~s}$ in $70 \%$ ethanol and for $10 \mathrm{~min}$ in a $50 \%$ Ace solution (commercial bleach). Media tested in the experiments were based on a modified Murashige and Skoog basal medium (MS) [14] supplied with: (i) plant growth regulators (PGRs): benzylaminopurine (BAP), 2,4-dichlorophenoxyacetic acid (2,4-D), indole3-acetic acid (IAA), kinetin (KIN), 1-naphthaleneacetic acid (NAA), 2,3,5-triiodobenzoic acid (TIBA), thidiazuron (TDZ); (ii) other organic and inorganic substances: 2-(Nmorpholin) ethanesulfonic acid (MES), potassium nitrate $\left(\mathrm{KNO}_{3}\right)$, putrescine; (iii) different sucrose concentrations (1, 2, 3 or $12 \%)$. Media were solidified with $8 \%$ agar (Difco, USA). In total, 36 different media were tested (Tab. 1). For statistical analysis, data from selected media (from six callus induction media and three regeneration media) were used (Tab. 2). After two or four weeks of culture, calli obtained on media $2 \mathrm{a}, \mathrm{b}, \mathrm{c}, 4,8,14$ were transferred onto media $17 \mathrm{c}$, $25 \mathrm{a}, \mathrm{b}$ for indirect regeneration (Tab. 2). Leaf segments were cultured on $90 \mathrm{~mm}$ Petri dishes (5 per one Petri dish) and other explants were grown on $55 \mathrm{~mm}$ Petri dishes (5 petioles or stem fragments or 4 apical meristems per one Petri dish) at $26 \pm 3^{\circ} \mathrm{C}$ in darkness for the induction of calli or in a $16 / 8 \mathrm{~h}$ photoperiod under cool-white fluorescent tubes (60-90 mol photons $\mathrm{m}^{-2} \mathrm{~s}^{-1}$ ) for regeneration. The contamination rate (bacterial or fungal) was ca. $10 \%$.

\section{Histological analysis}

For histological analysis stem fragments, after 0, 6 and 10 days of culture on MS with $1.0 \mathrm{mg} \mathrm{l}^{-1}$ 2,4-D (medium 3 b, Tab. 1), were used. The material was fixed in $5 \%$ glutaraldehyde in a $0.1 \mathrm{M}$ phosphate buffer, $\mathrm{pH} 7.2$ at room temperature for $2 \mathrm{~h}$, washed four times in the same buffer and dehydrated in a graded ethanol series and kept overnight in absolute ethanol. Then, the material was embedded in Technovit 7100 (2-hydroxyethyl-methacrylate) according to manufacturer's instructions (Heraeus Kulzer). The material was sectioned into $5 \mu \mathrm{m}$ with a rotary microtome (Microm, Adamas Instrumenten), stained with $0.1 \%$ toluidine blue $\mathrm{O}$ (TBO) and mounted in Entellan synthetic resin (Merck). Some sections were stained using periodic acid Schiff (PAS)/ TBO double staining. The semi-thin sections were treated with $0.5 \%$ periodic acid for $10 \mathrm{~min}$ and rinsed in distilled $\mathrm{H}_{2} \mathrm{O}$ for $3 \mathrm{~min}$. Sections were then stained with Schiff's reagent for $30 \mathrm{~min}$ and rinsed in a rinsing solution $(1 \mathrm{~mol} / \mathrm{l}$ $\mathrm{HCl} 5 \mathrm{ml}+10 \% \mathrm{Na}_{2} \mathrm{~S}_{2} \mathrm{O}_{5} 5 \mathrm{ml}+$ distilled $\left.\mathrm{H}_{2} \mathrm{O} 100 \mathrm{ml}\right)$. Then, the sections were stained with $0.1 \%$ TBO. In the PAS reaction, the total carbohydrates of insoluble polysaccharides (e.g., starch and cellulose) stain magenta to purplish red. TBO is
Tab. 1 Media tested in experiments, based on MS [8] supplemented with different plant growth regulators (PGRs), additional substances and different sucrose concentration (3\% in all media except for 17 and $25 \mathrm{~b}$ ).

\begin{tabular}{|c|c|}
\hline Medium No. & $\begin{array}{l}\text { Plant growth regulators and other substances } \\
\text { (concentration in } \mathrm{mg} \mathrm{l}^{-1} \text { ) }\end{array}$ \\
\hline \multicolumn{2}{|c|}{ Callus induction } \\
\hline 1 & without PGRs \\
\hline $2 a, b, c$ & $\operatorname{TDZ}(0.25,0.5,0.75)$ \\
\hline $3 a, b, c, d$ & $2,4-\mathrm{D}(0.5,1.0,2.5,5.0)$ \\
\hline 4 & $2,4-\mathrm{D}(0.2)+\mathrm{KIN}(0.04)$ \\
\hline 5 & $2,4-\mathrm{D}(0.2)+\mathrm{KIN}(0.04)+\mathrm{KNO}_{3}(5000)$ \\
\hline 6 & $2,4-\mathrm{D}(0.2)+\mathrm{KIN}(0.04)+\mathrm{KNO}_{3}(5000)+\mathrm{MES}(700)$ \\
\hline 7 & $2,4-\mathrm{D}(0.2)+\mathrm{KIN}(0.04)+$ putrescine $(800)$ \\
\hline 8 & $2,4-\mathrm{D}(2.0)+\mathrm{BAP}(1.0)$ \\
\hline $9 a, b, c, d$ & $2,4-\mathrm{D}(0.5,1.0,2.5,5.0)+\mathrm{BAP}(0.5)$ \\
\hline 10 & NAA $(0.1)+$ BAP $(1.0)$ \\
\hline 11 & $\mathrm{NAA}(0.1)+\mathrm{BAP}(1.0)+\mathrm{KNO}_{3}(5000)$ \\
\hline 12 & NAA $(0.1)+\mathrm{BAP}(1.0)+$ putrescine $(800)$ \\
\hline 13 & NAA $(1.0)+\mathrm{BAP}(1.0)$ \\
\hline 14 & $\mathrm{NAA}(0.25)+\mathrm{IAA}(0.025)+\mathrm{BAP}(0.25)$ \\
\hline 15 & $\mathrm{BAP}(0.1)+\mathrm{TIBA}(500)$ \\
\hline 16 & $\mathrm{BAP}(2.0)$ \\
\hline
\end{tabular}

Regeneration

\begin{tabular}{ll}
\hline $17 \mathrm{a}, \mathrm{b}, \mathrm{c}$ & without PGRs, 1,2 or $12 \%$ sucrose \\
18 & TDZ $(1.0)$ \\
19 & BAP $(0.5)$ \\
20 & $2,4-\mathrm{D}(0.5)+\mathrm{KIN}(1.0)$ \\
21 & $2,4-\mathrm{D}(0.5)+\mathrm{KIN}(2.0)$ \\
22 & NAA $(0.1)+\mathrm{KIN}(0.5)$ \\
23 & NAA $(0.1)+\operatorname{BAP}(0.2)$ \\
24 & NAA $(0.5)+$ BAP $(0.1)$ \\
$25 \mathrm{a}, \mathrm{b}$ & BAP $(1.5), 3 \%$ or $12 \%$ sucrose \\
\hline
\end{tabular}

routinely used as a counterstain in order to improve contrast. Microscopy sections were photographed with a Zeiss Axio Cam MRe digital camera. The images were processed with Zeiss Axio Vision 3.0 software.

\section{SEM analysis}

Cultured stem fragments were prefixed in 5\% glutaraldehyde (in 0.1 M phosphate buffer, $\mathrm{pH}$ 7.2) for $2 \mathrm{~h}$ at room temperature. After dehydration through a graded ethanol series, the samples were dried using a CPD system $\left(\mathrm{CO}_{2}\right.$ critical point drying), sputter-coated with gold (Jeol JFC$1100 \mathrm{E}$ ion-sputtering system) and observed with a Jeol JSM 5410 scanning electron microscope.

\section{TEM analysis}

Cultured stem fragments were fixed in $2.5 \%$ formaldehyde (prepared from paraformaldehyde) and 2.5\% glutaraldehyde in a $0.1 \mathrm{M}$ cacodylate buffer $(\mathrm{pH} 7.0)$ for $2 \mathrm{~h}$ at room 
Tab. 2 Selected media and explants used for callus induction and organogenesis. Media based on MS [8] with plant growth regulators (PGRs) and different sucrose concentration (3\% in all media except for $17 \mathrm{c}$ and $25 \mathrm{~b}$ ). Media are coded as in Tab. 1 .

\begin{tabular}{|c|c|c|c|}
\hline $\begin{array}{l}\text { Medium } \\
\text { No. }\end{array}$ & $\begin{array}{l}\text { PGR } \\
\text { (concentration } \\
\text { in } \mathrm{mg} \mathrm{l}^{-1} \text { ) }\end{array}$ & Explant & \\
\hline \multicolumn{3}{|c|}{ Callus induction } & $\begin{array}{l}\text { No. of explant } \\
\text { used/No. of } \\
\text { explants with } \\
\text { callus induction }\end{array}$ \\
\hline \multirow[t]{5}{*}{$2 a$} & TDZ (0.25) & apical meristem & $16 / 16$ \\
\hline & & petioles & $75 / 0$ \\
\hline & & leaves ventral & $75 / 0$ \\
\hline & & leaves dorsal & $25 / 0$ \\
\hline & & stem & $25 / 0$ \\
\hline \multirow[t]{5}{*}{$2 b$} & TDZ (0.50) & apical meristem & $14 / 14$ \\
\hline & & petioles & $75 / 0$ \\
\hline & & leaves ventral & $75 / 0$ \\
\hline & & leaves dorsal & $25 / 0$ \\
\hline & & stem & $75 / 21$ \\
\hline \multirow[t]{5}{*}{$2 c$} & TDZ (0.75) & apical meristem & $16 / 16$ \\
\hline & & petioles & $75 / 0$ \\
\hline & & leaves ventral & $75 / 0$ \\
\hline & & leaves dorsal & $25 / 0$ \\
\hline & & stem & $75 / 19$ \\
\hline \multirow[t]{5}{*}{4} & $\begin{array}{l}2,4-\mathrm{D}(0.2)+ \\
\operatorname{KIN}(0.04)\end{array}$ & apical meristem & $15 / 15$ \\
\hline & & petioles & $75 / 12$ \\
\hline & & leaves ventral & $75 / 48$ \\
\hline & & leaves dorsal & $75 / 45$ \\
\hline & & stem & $75 / 27$ \\
\hline \multirow[t]{5}{*}{8} & $\begin{array}{l}2,4-\mathrm{D}(2.0)+ \\
\operatorname{BAP}(1.0)\end{array}$ & apical meristem & $16 / 16$ \\
\hline & & petioles & $75 / 4$ \\
\hline & & leaves ventral & $76 / 54$ \\
\hline & & leaves dorsal & $75 / 57$ \\
\hline & & stem & $75 / 69$ \\
\hline \multirow[t]{5}{*}{14} & $\begin{array}{l}\text { NAA }(0.25)+ \\
\text { IAA }(0.025)+ \\
\text { BAP }(0.25)\end{array}$ & apical meristem & $16 / 15$ \\
\hline & & petioles & $75 / 6$ \\
\hline & & leaves ventral & $75 / 45$ \\
\hline & & leaves dorsal & $75 / 60$ \\
\hline & & stem & $75 / 30$ \\
\hline \multicolumn{2}{|c|}{ Regeneration } & & $\begin{array}{l}\text { No. of explant } \\
\text { used/No. of } \\
\text { regenerants }\end{array}$ \\
\hline $17 \mathrm{c}$ & $\begin{array}{l}\text { without PGRs + } \\
12 \% \text { sucrose }\end{array}$ & callus & $110 / 0$ \\
\hline $25 \mathrm{a}$ & BAP (1.5) & callus & $110 / 0$ \\
\hline $25 b$ & $\begin{array}{l}\text { BAP }(1.5)+12 \% \\
\text { sucrose }\end{array}$ & callus & $105 / 0$ \\
\hline
\end{tabular}

temperature. The samples were rinsed four times in the same buffer (15 min each) and post-fixed in buffered $1 \% \mathrm{OsO}_{4}$ at $4^{\circ} \mathrm{C}$ overnight. After rinsing in distilled water, explants were treated with $1 \%$ uranyl acetate for $1 \mathrm{~h}$, dehydrated in a graded acetone series and embedded in Spurr's resin. Ultrathin sections were cut on a Sorvall MT-2B ultramicrotome, stained with uranyl acetate and lead citrate, and examined with a Philips CM 100 transmission electron microscope. Control semi-thin sections were post-stained with $0.1 \% \mathrm{TBO}$.

\section{Statistical analysis}

All of the analyses and graphs were done in the R environment for statistical computing [15]. The data from six different media and five different explants (Tab. 2) were compared using a pairwise comparison between pairs of proportions with a correction for multiple testing (pairwise. prop.test function from stats library). Confidence interval values on bar charts were calculated by tests of proportion (prop.test from stats library).

\section{Results}

\section{Callus induction and culture}

Single callus cells were observed on stem discs (Fig. 1a) one week after inoculation. In subsequent days of culture, calli proliferated on callus induction and regeneration media on all explants used (Tab. 2 and Fig. 1b-d). The color of the callus depended on light conditions. In the dark, calli were white or cream, while in the light they turned green. The efficiency of callus production was explant and medium dependent. The frequency of callogenesis from apical meristems was $100 \%$ on almost all of the media. Fragments of stem and leaf blades responded with a lower frequency (Fig. 2a-c) and were not influenced by explant position on the medium (dorsal or ventral surface). The lowest response was noted when petioles (Fig. $2 \mathrm{a}-\mathrm{c}$ ) were used as explants. Callus tissue was produced without morphogenic response on all of the media used (Tab. 2).

\section{Histological and ultrastructural studies}

Histological analysis of callus induced from stems indicated that cell proliferation started primarily in the cortex (Fig. 3a). In subsequent days of the culture, centers of intense callus proliferation were visible in the cambial zone, phloem and xylem. The PAS reaction did not reveal starch grains in the cells of explants (data not shown). SEM observations confirmed that callus cells were induced in the cortex (Fig. 3b) and vascular bundles of stem discs. In well-developed callus, cells differed conspicuously in size and shape (Fig. 3c). Some parts of stem-derived callus (Fig. 3d) were covered with a membranous structure.

Ultrastructural studies of callus cells analyzed using TEM showed the presence of a wavy plasmalemma, profiles of a rough endoplasmic reticulum, dictyosomes, ribosomes and polysomes, which are typical for plant cells with a high level of activity (Fig. 3e-g). Fibrillar and globular structures were present in the intercellular spaces. Numerous mitochondria were located near lipid bodies. Parenchymatous, senescent cells showed a sequestration of the cytoplasm (Fig. 3e) and 

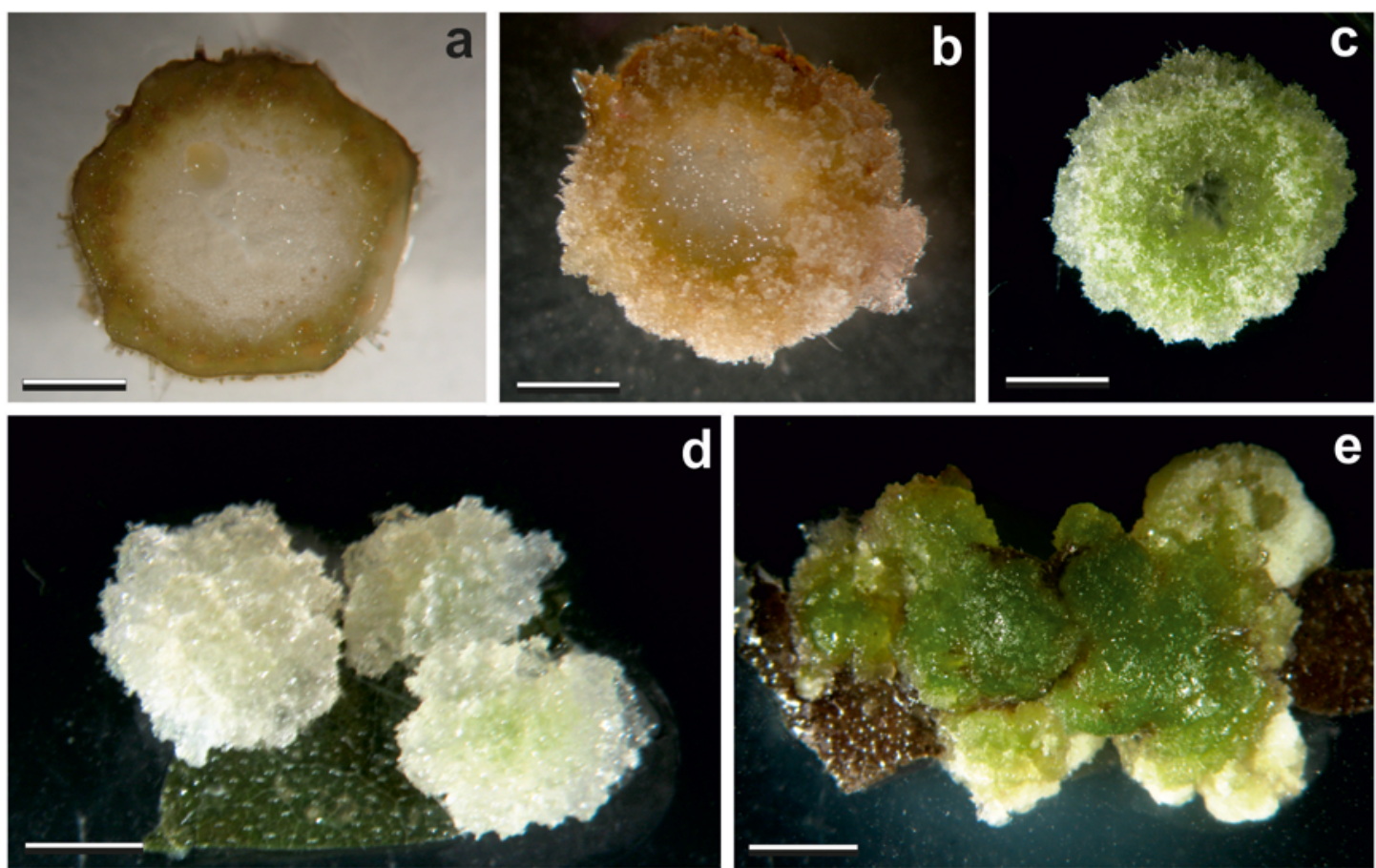

Fig. 1 Explants of stem discs (a-c) and leaf blade (d,e) cultured on MS medium with $0.5 \mathrm{mg} \mathrm{l}^{-1} \mathrm{KIN}$ and $0.1 \mathrm{mg} \mathrm{l^{-1 }}$ NAA. Explant at inoculation (a). Callus on explant surface after $4(\mathbf{b}, \mathbf{c})$ and 3 weeks of culture (d,e). Scale bars: $3 \mathrm{~mm}(\mathbf{a}-\mathbf{c}) ; 1 \mathrm{~mm}(\mathbf{d}, \mathbf{e})$.
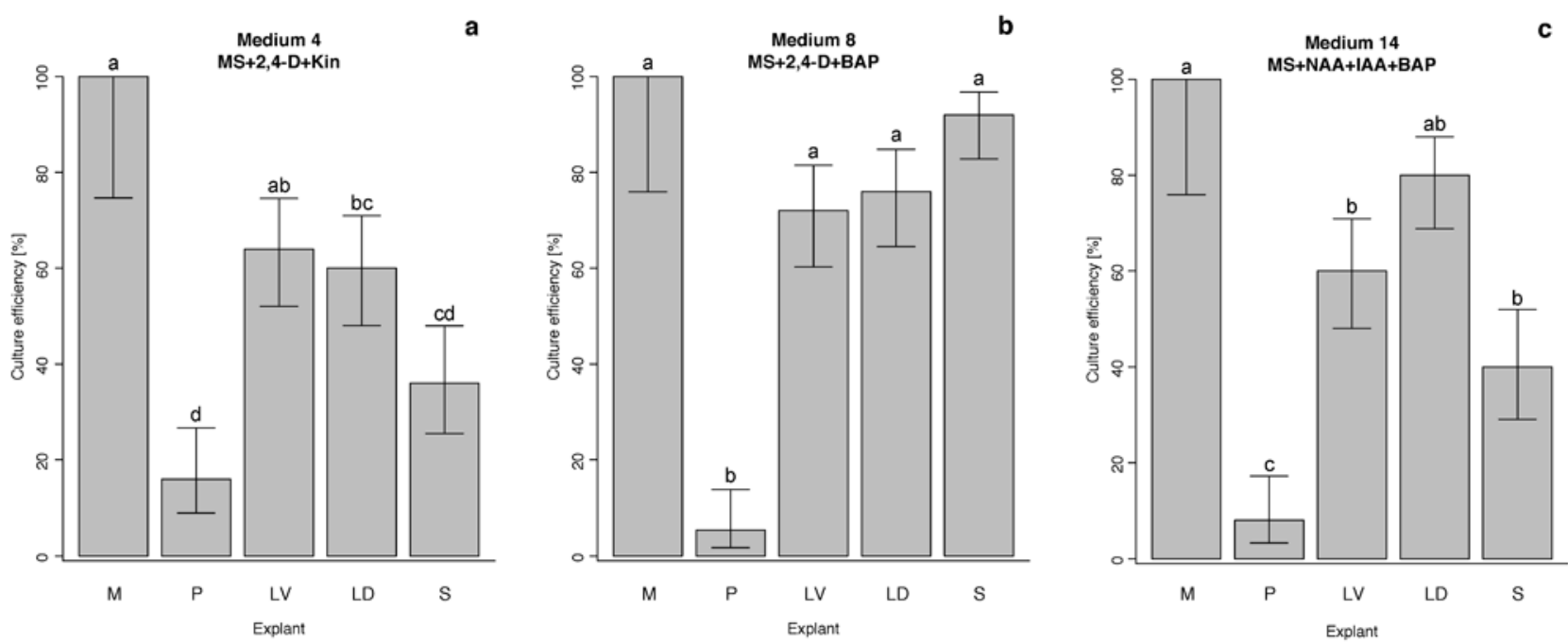

Fig. 2 a-c Effect of explant and medium on callus induction. Groups labelled with the same letter do not differ significantly $(P>0.05)$ by test of proportion. Error bars indicate $95 \%$ confidence intervals. Type of explants: M - meristems, P - petioles, LV - leaves ventral, LD - leaves dorsal, $\mathrm{S}$ - stem. Media are coded as in Tab. 1.

vacuoles containing electron-dense deposits, probably tannins (data not shown). On the surface of callus, fibers that extended from the outer cell wall were visible (Fig. 3h,i). The structure of the material covering the outer cell wall was different than the filling in the intercellular spaces. Compact material, composed of fibers and clumps, was located on the cell wall (Fig. 3g-i), whereas fibrillar and globular structures were present in the intercellular spaces (Fig. 3e,f).

\section{Discussion}

In our experiment we induced callogenesis in in vitro cultures of $H$. tuberosus cv. Albik. However, during the time of the culture, callus remained non-regenerative and no shoots, roots or somatic embryos were observed. Most of the regeneration media used in this study were previously tested with $H$. tuberosus or interspecific Helianthus hybrids where 

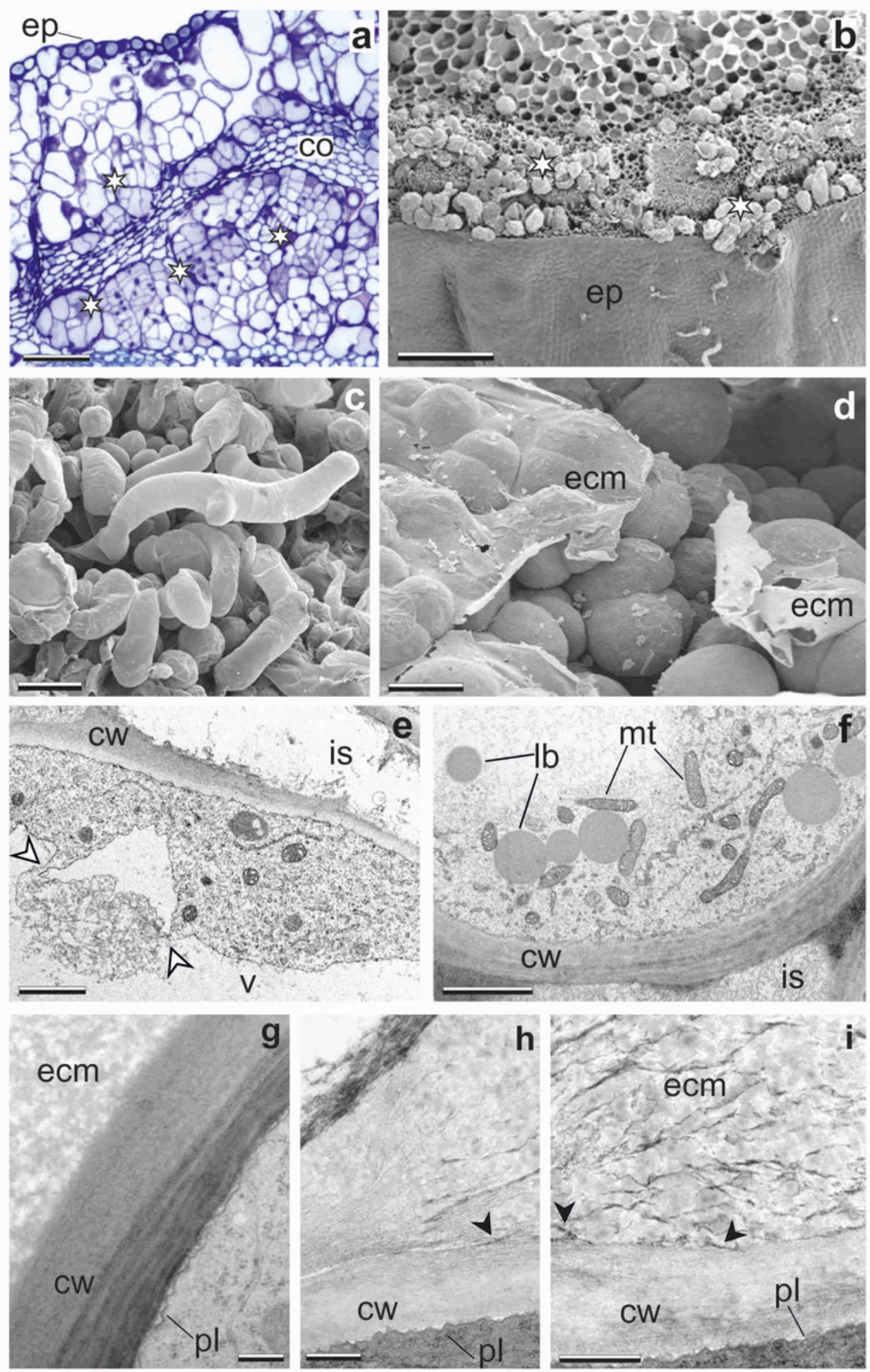

Fig. 3 Transversal section of stem explant after 10 days of culture (a) stained with TBO; high magnification of the cortex zone; visible epidermis (ep), cells of calli (asterisks) and remnants of collenchyma (co). SEM images of explants after 10 days (b) and 4 weeks (c,d) of culture. Cross sections of stem (b); visible epidermis (ep) and cells of callus (asterisks) in the cortex. Well-proliferated calli with cells differ in size and shape (c) and covered with ECMSN (ecm; d). TEM images of explants (e-i). Ultrastructure of meristematic cells (f), parenchymatic, senescent cells (e) and outer cell wall (g-i). Note wavy plasmalemma (pl), cell wall (cw), fibrillar and globular structures in the intercellular spaces (is). e White arrowheads indicate the sequestration of the cytoplasm and vacuole (v). f Visible numerous mitochondria (mt) near lipid bodies (lb). g-i Fragments of the surface of callus with a heterogenous ECMSN (ecm) with fibrills and clumps; black arrowheads indicate fibers extending from the outer cell wall. Visible lammellae of the cell wall $(\mathbf{g})$. Scale bars: $50 \mu \mathrm{m}$ $(\mathbf{a}, \mathbf{c}, \mathbf{d}) ; 200 \mu \mathrm{m}(\mathbf{b}) ; 1 \mu \mathrm{m}(\mathbf{e}, \mathbf{f}) ; 0.2 \mu \mathrm{m}(\mathbf{g}-\mathbf{i})$. 
plant regeneration by direct or indirect pathway was obtained [5-7,16-18]. In topinambur and sunflower cultures, the results highly dependent on the genotype, explant type and components of the nutrient medium [5-7,16-18]. Leaf segments of the interspecific hybrid $H$. annuus $\times H$. tuberosus were successfully used for morphogenesis and somatic embryogenesis [16]. However, in previous experiments on topinambur and sunflower hybrids [5], the frequency of formation of somatic embryos was very low. Bianchi et al. [6] reported that some genotypes of the genus Helianthus were able to regenerate plants with a high frequency, while other showed a complete absence of morphogenetic competence. A strong genotype-dependent tissue response under in vitro conditions has been reported for some taxa of monocots and dicots $[6,19,20]$.

Our results showed that callus was induced in the cortex and vascular bundles. It is commonly known that cambium cells are pluripotent vascular stem cells and retain the ability to divide [21,22]. A study by Rose et al. [23] on the origin of roots in leaf cultures of Medicago truncatula, showed that vein procambial cells stimulated by auxin gave rise to callus cells that ultimately generated root meristems. Further studies on regeneration in $M$. truncatula also revealed that somatic embryos in leaf cultures originated from procambial cells or dedifferentiated mesophyll cells that become totipotent [24]. Cell proliferation within the bundle sheath was also observed in leaf explants of $H$. occidentalis [25], leading to rhizogenesis.

The surface of non-regenerative callus derived from the cultivar Albik of $H$. tuberosus was covered with a membranous structure, similar to the ECMSN that has been reported in plant tissue cultures of different species [26-28]. Detailed TEM studies of topinambur calli have confirmed the extracellular deposition of fibrillar material and have

\section{Acknowledgments}

We would like to thank Plant Breeding and Acclimatization Institute in Radzików for providing tubers of topinambur cv. Albik. These studies were funded by the Rector of the Jagiellonian University for project AKCENT (2005. 2006).

\section{Authors' contributions}

The following declarations about authors' contributions to the research have been made: participation in in vitro culture experiments, histological technique, acquisition of in vitro data, documentation of in vitro and histological results and data interpretation, participation in drafting the article: MP; participation in in vitro culture experiments, acquisition, interpretation and documentation of scanning electron microscopy data, drafting the article: MPK; participation in in vitro culture experiments and in drafting the article: $H S ́$; acquisition, interpretation and documentation of transmission electron microscopy data: MKK; statistical analysis of data obtained in in vitro experiments: GG; participation in in vitro culture experiments and in drafting the manuscript: RK; acquisition, interpretation and documentation of scanning electron microscopy data, analysis and interpretation of transmission electron microscopy data, critical revision of electron microscopy part of the manuscript: JB; design of the study, contribution to interpretation of data, critical revision of the manuscript: EK.

\section{References}

1. Ma XY, Zhang LH, Shao HB, Xu G, Zhang F, Ni FT, et al. Jerusalem artichoke (Helianthus tuberosus), a medicinal salt-resistant plant has high adaptability and multiple-use values. J Med Plant Res. 2011;5(8):1272-1279. revealed the presence of globular structures and fibers in the intercellular spaces. A similar heterogeneous ECMSN was reported in oilseed rape where osmiophilic granules were associated with fibers extending from the outer cell wall of embryogenic callus cells [29]. ECMSN was primarily linked to the acquisition of embryogenic competence $[8,30]$ and in several species can serve as an early structural marker of somatic embryogenesis [29,31,32]. The presence of extracellular material also accompanied the induction of organogenesis [12,33]. However, in the present studies, in spite of the occurrence of ECMSN the calli were not morphogenetic. The extracellular layer covering callus cells, which is not involved in the regeneration process, has previously been reported during androgenesis in wheat [34], somatic embryogenesis in banana [35] and clover cultures [36]. The role of ECMSN cannot be generalized but it is evident that it is formed on the surface of cultured in vitro tissues regardless of its morphogenetic competence. Therefore, we agree with the suggestion that has been made by several authors $[26,30]$ that ECMSN formation could be a stress response of plant tissues that is triggered by specific culture conditions and that covering callus with extracellular material could provide protection against external factors.

\section{Conclusions}

Based on the previous reports and the results of the present experiment, it is evident that: (i) the morphogenic capacity of callus in Helianthus tuberosus is strictly genotype dependent, (ii) cultivar Albik is recalcitrant in in vitro regeneration, (iii) ECMSN is not a morphogenic marker in this cultivar.

2. Li XD, Miao FP, Ji NY. Two new epoxysteroids from Helianthus tuberosus. Molecules. 2011;16(12):8646-8653. http://dx.doi.org/10.3390/ molecules 16108646

3. Gutierrez Pesce P, Bizzarri M, Rugini E, de Pace C. In vitro microtuberization for simulating the developmental physiology of underground storage organ in Helianthus tuberosus. In: Proceedings of the joint meeting AGI-SIBV-SIGA. Assisi: SIGA; 2011. p. 6A.38.

4. Volk GM, Richards K. Preservation methods for Jerusalem artichoke cultivars. HortScience. 2006;41(1):80-83.

5. Pugliesi C, Megale P, Cecconi F, Baroncelli S. Organogenesis and embryogenesis in Helianthus tuberosus and in the interspecific hybrid Helianthus annuus $\times$ Helianthus tuberosus. Plant Cell Tissue Organ Cult. 1993;33(2):187-193. http://dx.doi.org/10.1007/BF01983233

6. Bianchi R, Fambrini M, Pugliesi C. Morphogenesis in Helianthus tuberosus: genotypic influence and increased totipotency in previously regenerated plants. Biol Plant. 1999;42(4):515-523. http://dx.doi. org/10.1023/A:1002698511484

7. Fambrini M, Cionini G, Conti A, Michelotti V, Pugliesi C. Origin and development in vitro of shoot buds and somatic embryos from intact roots of Helianthus annuus $\times$ H. tuberosus. Ann Bot. 2003;92(1):145151. http://dx.doi.org/10.1093/aob/mcg116

8. Verdeil JL, Hocher V, Huet C, Grosdemange F, Escoute J, Ferrière $\mathrm{N}$, et al. Ultrastructural changes in coconut calli associated with the acquisition of embryogenic competence. Ann Bot. 2001;88(1):9-18. http://dx.doi.org/10.1006/anbo.2001.1408

9. Šamaj J, Baluška F, Bobák M, Volkmann D. Extracellular matrix surface network of embryogenic units of friable maize callus contains 
arabinogalactan-proteins recognized by monoclonal antibody JIM4 Plant Cell Rep. 1999;18(5):369-374. http://dx.doi.org/10.1007/ s002990050588

10. Blehová A, Bobák M, Šamaj J, Hlinková E. Changes in the formation of an extracellular matrix surface network during early stages of indirect somatic embryogenesis in Drosera spathulata. Acta Bot Hung. 2010;52(1):23-33. http://dx.doi.org/10.1556/ABot.52.2010.1-2.3

11. Konieczny R, Bohdanowicz J, Czaplicki AZ, Przywara L. Extracellular matrix surface network during plant regeneration in wheat anther culture. Plant Cell Tissue Organ Cult. 2005;83(2):201-208. http:// dx.doi.org/10.1007/s11240-005-5771-9

12. Popielarska-Konieczna M, Kozieradzka-Kiszkurno M, Świerczyńska J, Góralski G, Ślesak H, Bohdanowicz J. Ultrastructure and histochemical analysis of extracellular matrix surface network in kiwifruit endosperm-derived callus culture. Plant Cell Rep. 2008;27(7):1137-1145. http://dx.doi.org/10.1007/s00299-008-0534-9

13. Bobák M, Šamaj J, Hlinková E, Hlavačka A, Ovečka M. Extracellular matrix in early stages of direct somatic embryogenesis in leaves of Drosera spathulata. Biol Plant. 2003;47(2):161-166. http://dx.doi. org/10.1023/B:BIOP.0000022245.64929.8b

14. Murashige T, Skoog F. A revised medium for rapid growth and bioassays with tobacco tissue culture. Physiol Plant. 1962;15(3):473-497. http://dx.doi.org/10.1111/j.1399-3054.1962.tb08052.x

15. R Core Team. R: a language and environment for statistical computing [Internet]. 2012 [cited 2013 Oct 20]; Available from: http:// www.R-project.org

16. Fambrini M, Cionini G, Pugliesi C. Development of somatic embryos from morphogenetic cells of the interspecific hybrid Helianthus annuus $\times$ Helianthus tuberosus. Plant Sci. 1996;114(2):205-214. http://dx.doi. org/10.1016/0168-9452(95)04320-9

17. Fambrini M, Cionini G, Pugliesi C. Acquisition of high embryogenic potential in regenerated plants of Helianthus annuus $\times H$. tuberosus. Plant Cell Tissue Organ Cult. 1997;51(2):103-110. http://dx.doi. org/10.1023/A:1005965628512

18. Gamburg KZ, Vysotskaya EF, Gamanets LV. Microtuber formation in micropropagated Jerusalem artichoke (Helianthus tuberosus). Plant Cell Tissue Organ Cult. 1998;55(2):115-118. http://dx.doi. org/10.1023/A:1006127319351

19. Popielarska-Konieczna M, Kozieradzka-Kiszkurno M, Tuleja M, Ślesak H, Kapusta P, Marcińska I, et al. Genotype-dependent efficiency of endosperm development in culture of selected cereals: histological and ultrastructural studies. Protoplasma. 2013;250(1):361-369. http:// dx.doi.org/10.1007/s00709-012-0419-1

20. Ślesak H, Góralski G, Pawłowska H, Skucińska B, PopielarskaKonieczna M, Joachimiak AJ. The effect of genotype on a barley scutella culture. Histological aspects. Cent Eur J Biol. 2013;8(1):30-37. http:// dx.doi.org/10.2478/s11535-012-0113-5

21. Fukuda H. Plant cell biology: signals that control plant vascular cell differentiation. Nat Rev Mol Cell Biol. 2004;5(5):379-391. http:// dx.doi.org/10.1038/nrm1364

22. Jura J, Włoch W, Kojs P, Wilczek A, Szendera W. Current trends in the structural investigations of the vascular cambium. Bull Bot Gard. 2005;14:43-47.
23. Rose RJ, Wang XD, Nolan KE, Rolfe BG. Root meristems in Medicago truncatula tissue culture arise from vascular-derived procambial-like cells in a process regulated by ethylene. J Exp Bot. 2006;57(10):22272235. http://dx.doi.org/10.1093/jxb/erj187

24. Wang XD, Nolan KE, Irwanto RR, Sheahan MB, Rose RJ. Ontogeny of embryogenic callus in Medicago truncatula: the fate of the pluripotent and totipotent stem cells. Ann Bot. 2011;107(4):599-609. http://dx.doi. org/10.1093/aob/mcq269

25. Šamaj J, Bobák M, Kubošníková D, Krištín J, Kolarik E, Ovečcka M, et al. Bundle sheath cells are responsible for direct root regeneration from leaf explants of Helianthus occidentalis L. J Plant Physiol. 1999;154(1):89-94. http://dx.doi.org/10.1016/S0176-1617(99)80322-8

26. Dubois T, Dubois J, Guedira M, Diop A, Vasseur J. SEM characterization of an extracellular matrix around somatic proembryos in roots of Cichorium. Ann Bot. 1992;70(2):119-124.

27. Popielarska-Konieczna M, Bohdanowicz J, Starnawska E. Extracellular matrix of plant callus tissue visualized by ESEM and SEM. Protoplasma. 2010;247(1-2):121-125. http://dx.doi.org/10.1007/ s00709-010-0149-1

28. Mazarei M, Al-Ahmad H, Rudis MR, Joyce BL, Stewart CN. Switchgrass (Panicum virgatum L.) cell suspension cultures: establishment, characterization, and application. Plant Sci. 2011;181(6):712-715. http://dx.doi.org/10.1016/j.plantsci.2010.12.010

29. Namasivayam P, Skepper J, Hanke D. Identification of a potential structural marker for embryogenic competency in the Brassica napus spp. oleifera embryogenic tissue. Plant Cell Rep. 2006;25(9):887-895. http://dx.doi.org/10.1007/s00299-006-0122-9

30. Šamaj J, Bobák M, Blehová A, Krištin J, Auxtová-Šamajová O. Developmental SEM observations on an extracellular matrix in embryogenic calli of Drosera rotundifolia and Zea mays. Protoplasma. 1995;186(1-2):45-49. http://dx.doi.org/10.1007/BF01276934

31. Šamaj J, Bobák M, Blehová A, Pret’ová A. Importance of cytoskeleton and cell wall in somatic embryogenesis. In: Mujib A, Šamaj J, editors. Somatic embryogenesis. Berlin: Springer; 2006. p. 35-50. (vol 2). http://dx.doi.org/10.1007/7089_024

32. Lai KS, Yusoff K, Maziah M. Extracellular matrix as the early structural marker for Centella asiatica embryogenic tissues. Biol Plant. 2011;55(3):549-553. http://dx.doi.org/10.1007/s10535-011-0123-6

33. Konieczny R, Świerczyńska J, Czaplicki AZ, Bohdanowicz J. Distribution of pectin and arabinogalactan protein epitopes during organogenesis from androgenic callus of wheat. Plant Cell Rep. 2007;26(3):355-363. http://dx.doi.org/10.1007/s00299-006-0222-6

34. Pilarska M, Czaplicki AZ, Konieczny R. Patterns of pectin epitope expression during shoot and root regeneration in androgenic cultures of two wheat cultivars. Acta Biol Crac Ser Bot. 2007;49:69-72.

35. Xu C, Zhao L, Pan X, Šamaj J. Developmental localization and methylesterification of pectin epitopes during somatic embryogenesis of banana (Musa ssp. AAA). PLoS ONE. 2011;6(8):e22992. http:// dx.doi.org/10.1371/journal.pone.0022992

36. Pilarska M, Knox JP, Konieczny R. Arabinogalactan-protein and pectin epitopes in relation to an extracellular matrix surface network and somatic embryogenesis and callogenesis in Trifolium nigrescens Viv. Plant Cell Tissue Organ Cult. 2013;115(1):35-44. http://dx.doi. org/10.1007/s11240-013-0337-8 